\title{
URBAN TOURISTIC DEVELOPMENT IN THE COASTAL CITIES: CASE STUDY: AQABA, ALEXANDRIA, ANNABA AND CASABLANCA CITIES
}

\author{
Foued BENGHADBANE* \\ University 'Larbi Ben M'hidi', Institute of Management of the Urban Techniques, \\ Oum El Bouaghi, Algeria, e-mail: fouad.benghadbane @ gmail.com

\section{Sawsan KHRIES} \\ Yarmouk University, Faculty of Tourism and Hotel Management, \\ Irbid, Jordan, e-mail: sawsankhries @ yahoo.com
}

\begin{abstract}
Citation: Benghadbane, F. \& Khries, S. (2020). URBAN TOURISTIC DEVELOPMENT IN THE COASTAL CITIES: CASE STUDY: AQABA, ALEXANDRIA, ANNABA AND CASABLANCA CITIES. GeoJournal of Tourism and Geosites, 29(2), 488-507. https://doi.org/10.30892/gtg.29209-484
\end{abstract}

\begin{abstract}
This research aims at clarifying the various opportunities offered by tourist destinations in the Arab cities (Aqaba, Alexandria, Annaba and Casablanca) from four different countries, which allow identifying the various obstacles that can pose challenges through which a comprehensive strategy for the development of urban tourism can be drawn up. The four cities (Aqaba, Alexandria, Annaba and Casablanca) are studied as case studies for this research. The directorates of tourism, traditional industries and some websites are used to obtain statistical data related to the number of tourists visiting urban destinations in the studied cities, which allowed showing paradoxes among them that increase when there is a focus on Arab coastal cities. The analytical descriptive approach was used to diagnose the various opportunities of urban tourism as well as the comparative approach to identify the different paradoxes between the four cities at the levels of urban tourism development achieved. The results revealed the practice of many urban tourism activities in the four cities, which face many challenges related to the industry sector and the consequent emergence of pollution in various forms, in addition to the seasonal tourist market and the spread of chaotic housing. This is considered as an obstacle that prohibits the enhancement of its urban tourism development.
\end{abstract}

Key words: Touristic destination, urban tourism, opportunities, challenges, Coastal cities

\section{INTRODUCTION}

The economic and social transformations in cities have, during the last years, contributed to the reconstruction of their urban structures, as a response to their tendency to embrace open society, which is in need for more social mobility, recreation

\footnotetext{
* Corresponding author
}

http://gtg.webhost.uoradea.ro/ 
and cultural activities (Blaževic \& Nižic, 2015). This has led to new transformations in the uses of various fields in the urban areas (Hayllar et al., 2008), where the cities have started working on creating many aspects of entertainment, recreation and leisure. Whether by exploiting the existing heritage buildings or by finding more modern new areas, matching to what have been found by the information and telecommunication technology revolution (Renau, 2018), which has made the concept of tourism loses its traditional meaning, concentrated on travel for the purpose of discovering other places characterized by their different cultures and customs; or to the purpose of travelling to practice urban tourism in a new concept, that is the "urban tourism" (Griffin \& Hayllar, 2009). Although entertainment and leisure are among the most important urban activities in cities, that have become tourist attractions, they are subjected to urban planning in their availability and distribution in a manner that guarantees quality and excellence in the urban environment, and allows the local population participation in consolidating the values of identity and belonging (Yildiz \& Akbulut, 2013).

In the context of urban tourism, recreation and entertainment areas emerge as a chain of concerte and integrated natural, historical, urban and human attractions, in addition to the facilities, the services and the constructions that might be available and influencing in their intended destination to visit them and stay in them for a period of time (Cave \& Jolliffe, 2012). This will increase number of visitors and extend their duration of stay which will have an increase revenue; this is known as urban touristic development, which is concerned with the upgrading and the expanding of touristic services and needs in the framework of a strong competition among the cities touristic destinations, to providing regenerated potentials, to attract tourist, in various ways (Gârbea, 2013), so the cities that could accommodate most of the tourists are large multi-functional entities, that would easily accommodated tourists, where many of the urban facilities and services could be intensively utilized (Jiménez et al., 2017), but little of the city was created specifically for the touristic us. It is worth mentioning that tourism contributes in great economic benefits to cities, especially those cities whose economies rely heavily on tourism. These cities can acquire a large and varied economic base, and can have much benefit from tourism. At the same time, these cities are less dependent on urban tourism (Ashworth, 2011).

Urban tourism has begun to demonstrate a great importance in all aspects ans in many cities of the world; urban interventions have led to a shift in the style of life (Nogués-Pedregal, 2019), that were particular to many ancient historical places (BarreraFernandez et al., 2016). These areas have become, as well, constituting the most embracing part of implementing urban policies (Wu et al., 2018), and controlling the direction of flow of tourists and thus represents a domain of strategic function of cities (Vles, 2011). We will try, in this regard, to clarify in this research, the tourism destinations, that activate urban touristic development in a number of Arab coastal cities, and the investment in such countries, as one of the traditional touristic opportunities alternatives, and to clarify the paradoxes existing between the current situation in practicing urban tourism and the mechanism of exploiting entertainment and recreation areas, in light of the challenges imposed by the economic and social development policies adopted in each city, and the prospects drawn for urban touristic development.

The cities, especially the large cities, form the most important touristic destinations in the world. They are major links to the system of air transportation to different geographical regions of the world. Therefore, they receive local and international tourists; they attract an increasing number of tourists every year. City tourism, which is also known as urban tourism, is a sort of touristic trips made by tourists to cities or to world populated places for short periods between one day and 
three days (Nogués-Pedregal, 2019). According to statistics of the Tourists World Organization, the number of international tourists has risen steadily, and that 100 leading cities in the world witnessed in 2013 the arrival of foreign tourists in a growth ratio reach to $5.4 \%$. The importance of urban tourism is also evident in traffic trends during the holidays. The percentage of beach tourism reached $31 \%$ during the past five years. The percentage of touristic journey towards the cities grows also up to $21 \%$ over the past five years. This latter percentage is known to vary among the cities of the world, while it is clearly rising in cities with beaches, it is ranging between $38-42 \%$ (Bock, 2015). However, on the Continents level, urban tourism is growing rapidly in the economies of developed and developing countries. In 2014, the market share of the city's holidays was 21\% in Europe, $17 \%$ in North America, 25\% in Asia and the Pacific and 22\% in Latin America. This creates employments in urban cities (Postma et al., 2017). In order to achieve this outcome, they consume large areas within urban areas to provide entertaining parks, leisure and recreational areas. Since the fifties of last century, urban tourism has given keen interest in the Arab cities, that has been organized to develop their economies, which was appropriate and right in this choice.

It is necessary to envisage a rational urban tourism management ensuring the ability to respond to the expectations of tourists, the image of the city and the normal life of its inhabitants (Al-Saad \& Ababneh, 2017). The cities of Aqaba (Jordan), Alexandria (Egypt), Annaba (Algeria) and Casablanca (Morocco) demonstrate an appropriate example illustrating the importance of urban touristic development in coastal cities, that are geographically dispersed in variant urban environments and enjoy potentials and opportunities for diverse urban tourism, coming out from the privacy of their locations, ancestry of history, urban structure, and the exploration of various obstacles and challenges associated with the development of urban tourism in the coastal Arab cities.

\section{LITERATURE REVIEW}

Urban tourism is considered as one of the most important forms of tourism on word level, but it has been given a little attention from researchers in both tourism and cities (Ashworth, 2003). Despite its importance, the concept of urban tourism remains inaccurate and somewhat ambiguous. Urban tourism first appeared in 1970, in the United Kingdom, Western Europe, and North America; the aim was to push forward the wheel of urban economy as a result to the economic deterioration of their cities (Murillo et al., 2013). Consequent to the positive results urban tourism caused in many cities of the world, most governments have in recent years, found it necessary to augment at and develop such results, which once again gave rise to researching interest in urban tourism. However, this interest does not reflect the extent of importance tourism already enjoys in other destinations (Estelaji et al., 2012). With the global economic recovery of the 1980 s, from which many cities benefited in executing the urban innovating projects, which returned in benefit on those cities.

This is because those projects were areas of interest for the city tourists, which directly encouraged the promotion of urban tourism in them (Van Den Berg et al., 1995), who extensively worked to give concepts to the urban tourism, and to identify opportunities and challenges that tourism may face, that are greatly evident in all Dharmwani works in 2013, who took keen interest in the State of Rajasthan that acquires many tourist components such as customs, traditions, culture, food and traditional clothes that could be a model of tourism in India. However, the State of Rajasthan is facing many challenges, embodied in the undeveloped transport and communications networks, housing problems and absence of urban tourism management partners (Dharmwani, 2013). In Barcelona-Spain, Valls and colleagues dealt in 2013 with 
the issue of the significance of planning and management of urban tourism in Barcelona city, that was able within 15 years to achieve an increasing growth in the number of tourists and in the number of touristic nights till it became one of the most visited European cities been visited during challenges related to the competitiveness capability of the city, especially with the lack of spatial balance for distributing of the touristic destinations in the city, adding to that, the fierce competition on these destinations, between the city's residents and the tourists, and the lack of transport and other problems that require adoption of integrated and rational touristic management, in order to enhance touristic destinations and strengthen competitive ability, in order to return back the image and tourist status of Barcelona within the network of European cities (Valls et al., 2013).

It is worth mentioning that the State of Ethiopia has worked on the development of its urban tourism, especially in the capital Addis Abeba. This is reflected in the researches of Kidane-Mariam, who clarified possibilities that the city of Addis Abeba embodied, in the natural and cultural heritage, and the city's high level of urban development. Wherever low touristic services and the lack of qualified human resources hinders the urban tourism in the city. In addition to the study related to Hawassa city, which is very rich in natural and heritage resources, such as the Lake Hawassa, the Gudumalere creation area, the Smuda archeology, the Woldeamanuel, the Loke Palace, the Alamura and Tabor mountains and so on, which are considered touristic attraction areas in Hawassa city. However, these assets were not exploited, except Lake Hawassa, which was attracting large numbers of tourists. So the situation requires placing a rational management for these attractions to increase the number of tourists and to develop the urban tourism in the city (Kidane-Mariam, 2015). In Canada, the city of Montréal is promoted as a cultural and recreational tourist destination in order to develop the urban tourism. This was confirmed by 'Pradel' in his studies and research related to the city in 2015. Montréal was established as the 'city of festivals' that serves both its residents and tourists. So festivals became pillars of the cultural and tourist activity of the city, which contribute significantly to the economy. As a result, the city of Montréal seeks to be the capital of festivals and cultural performances to compete with New York, Boston, Quebec at the activities by involving various actors and decision makers (Pradel, 2015).

In London, urban tourism has been driven by sustainability as exemplified by Maxim in 2016, who considers that sustainability has received little attention in the development of urban tourism by city decision-makers through promotions as well as limited initiatives from sustainable tourism. Therefore, it is necessary to move towards achieving the sustainable urban landscape, especially with the noticeable improvement in the economic climate and the attention to social and environmental issues in London (Maxim, 2016). In addition to that, Bader and colleagues in 2016, were interested in analyzing the challenges and opportunities of urban tourism in Jordan, and many rehabilitated Jordanian cities, in the term of trends and developments, focusing on the city of Amman as a case study, by clarifying the concept of urban tourism and determining the role of urban areas in this type of tourism, as being touristic destinations and entry gates. He also discussed the evaluation of main elements that can attract tourists to urban areas, by providing new opportunities, and overcome difficulties and facing the challenges related to the development of Amman city as a center for urban tourism (Bader et al., 2016). In 2017, Shiji explained the concept of urban tourism and the factors influencing it, its basic elements (basic, secondary and additional), its economic, social and legislative impact, highlighting the status of urban tourism within the urban planning policies in India. In addition to his classification of the Indian touristic cities in 10 main categories according to their population volume and variant of their touristic 
potentials from one city to another. Therefore, developing the urban tourism in India is inevitable and it is to be encouraged by decision-makers (Shiji, 2017).

During the same year, Al-Saad and Ababneh, discussed in their two researches, the current status of Arab tourism, relying on the three Arab cities: Amman, Cairo and Dubai, highlighting the different opportunities and potentials of tourism development. Despite the success that Amman, Cairo and Dubai achieved as major destinations, they face some common challenges, and each city as well faces different challenges; which requires facing the significant major challenges, especially those related to seasonality, pollution, congestion, instability, competition and financing, in order to address the various problems in a systematic manner according to the requirements of cultural and urban tourism (Al-Saad \& Ababneh, 2017). With the growing of urban tourism significance in sustainable development. Hakeem and Khan in 2018 highlighted the concept of urban tourism, focusing on the characteristics of the urban city, the costs and benefits of urban tourism highlighting the city of Cambridge. They demonstrated that the local awareness and the governmental support strengthen the role of public and private sectors in urban tourism in Cambridge (Hakeem \& Khan, 2018). The interest in urban tourism has continued in many studies and researches that have necessitated the marketing of tourist destinations for urban development, as evidenced in the study of Benghadbane and Khreis in 2019 in a comparative study between the cities of Constantine (Algeria) and Amman (Jordan) There are significant differences in the marketing strategy of the tourism product in the cities of Constantine and Amman, accompanied by a sharp variation in the quality of tourism development projects from both cities, which are reflected by the numbers and categories of tourists coming to them (Benghadbane \& Khreis, 2019).

\section{METHODOLOGY}

The research aims at clarifying the opportunities that the coastal cities have a primordial role in developing urban tourism, through various recreational and entertaining areas of tourism, which allow drawing strategic plans for the development of urban tourism so the studied cities become Centers for urban and coastal tourism in the Arab world. In so, we will rely on the analytical descriptive approach that allows diagnosing the various opportunities available in the coastal cities, as well as the comparative approach to highlight all the differences between the four studied cities, and to show the levels of urban tourism development achieved, according to the different development policies adopted in each city. The researcher relied upon a set of theoretical references from books, research and studies to collect data and information related to the subject of research, to the field of research and to the domain of research, we mean the four cities that represent the case studies, which required the development of some tactical techniques to achieve clear results in the search.

\section{IMPORTANCE OF LOCATION ON THE ROUTES OF INTERNATIONAL TOURISM FLOWS}

The four studied cities (Aqaba, Alexandria, Annaba and Casablanca) have their strategic geographical locations in the Middle East and North Africa region, qualified them to play important role in the global tourism market. They are large coastal cities overlooking various water surfaces; the city of Aqaba in Jordan overlooks the Red Sea received many tourist and commercial flows, especially from commercial ships and cruise ships (Al-Saad et al., 2018). Alexandria, Egypt which is overlooking the Mediterranean Sea, nearby the Suez Canal is an important touristic destination for tourists crossing the Suez Canal onboard of the international cruise ships (Eldaidamony, 2011). 
The city of Annaba is located on the eastern side of the Algerian coast. Its Mediterranean location contributed to the influx of tourists (Cataldo, 1999). Casablanca, Morocco, overlooks the ocean. The Atlantic is open to all European, American, African and Australian directions. It is therefore a city that welcomes tourists in large numbers from different nationalities and from all regions of the world (Berriane, 2002) (Figure 1).

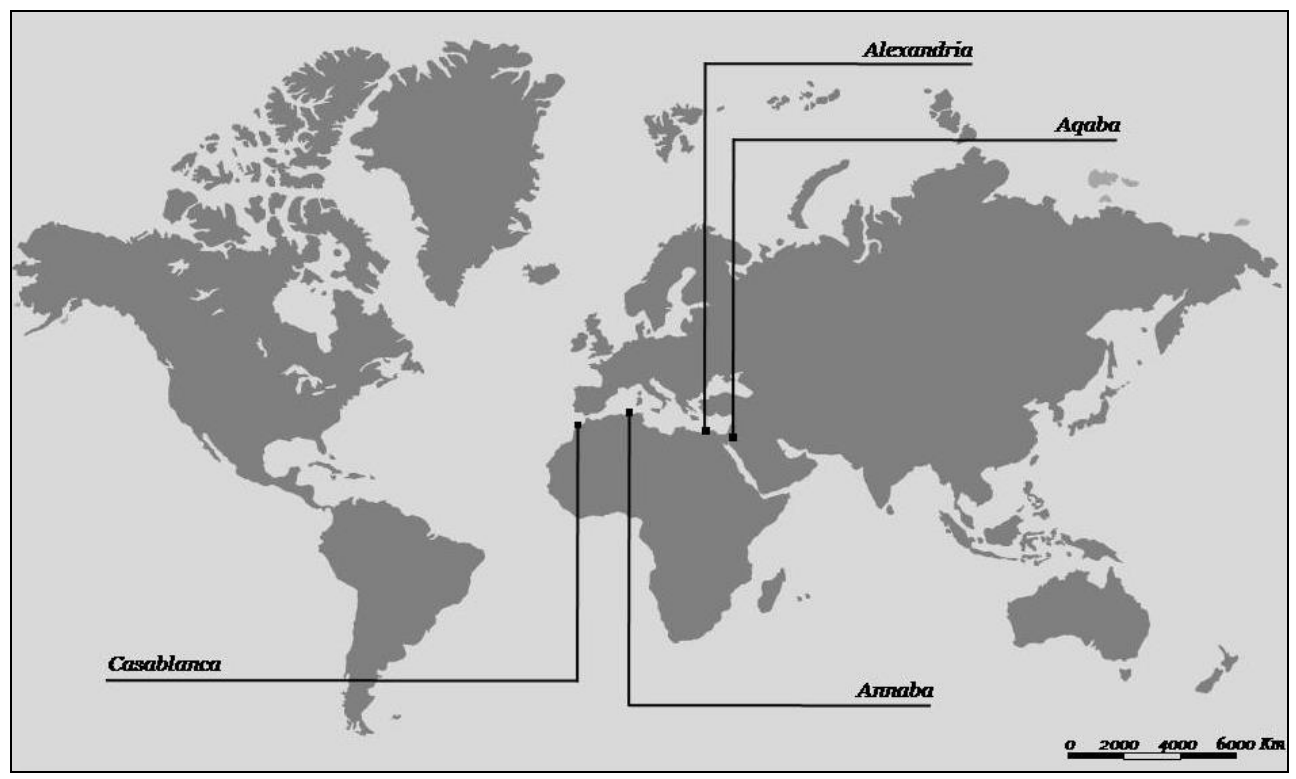

Figure 1. Geographical location of cities (Aqaba, Alexandria, Annaba and Casablanca) (Source: www.mapsofworld.com, 2018, Personal treatment for researchers, 2020)

Their strategic locations become more important, when we know that, each of these four cities has a double activity seaport (commercial and passengers transportation) as well as an international airport links the city with different destinations around the world. This makes the cities occupy important geographical locations in the international tourism directions, and enjoy touristic destinations required by different tourists of the world. In 2017, the number of international tourists visited to the Middle East and North Africa was about 80 million, it is highest number since 2011. The number of international tourists arriving in the Middle East increased by $5 \%$ with a total of 58 million tourists, by an increase of 3 million additional tourists in 2017 compared to 2016, this was due to the development of some touristic destinations and the improvement in their touristic services, especially when both Aqaba and Alexandria cities belong to the Middle East, thus they enjoy a large share of the tourists number. On the other hand, the area of North Africa in which the two cities of Annaba and Casablanca are located have registered growth in the number of international tourists arrivals, amounted to about $13 \%$, with a total of 21 million tourists, with an additional of 3 million tourists in 2017 compared to 2016 (WTO Committee for the Middle East, 2018).

THE POTENTIAL DIVERSITY OF THE COASTAL DESTINATIONS AND THE ASSOCIATED TOURISM ACTIVITIES

The city of Aqaba is located in the far south of Jordan. It is about $330 \mathrm{~km}$ away from the capital Amman and $80 \mathrm{~km}$ from Petra. It has a population of about 148,398 in 
2015 (Hashemite Kingdom of Jordan, 2016), making it the fifth largest city in the Hashemite Kingdom of Jordan. Its strategic position on the Red Sea at the intersection of roads linking Asia, Africa and Europe attracted many civilizations such as Nabateans to use the port of Aqaba for their trade (Khreis, 2016). Aqaba became increasingly important through its port, which played an important role after the establishment of the Hashemite Kingdom of Jordan in 1946, especially in the transit trade Iraq and northern Saudi Arabia, as well as in the transfer of oil, a pipeline 'Tabline' from Saudi Arabia to the ports of the Mediterranean (Al- Nasarat, 2012). As a result of this site-specificity, the city of Aqaba has gained an important place with in the Jordanian tourist cities as well as its economic importance as the only maritime port linking Jordan to the world via the Red Sea. It is also a center for receiving tourists visiting the various tourist attractions in Aqaba, (Attaallah \& Al-Ehewat, 2014) because of its closeness accessibility, the possibility of spending the longest time with the port and the King Hussein International Airport (Amira, 2011). Aqaba embraces many attractions including the Aqaba historical sites such as: Mamluk fortress, established in the sixteenth century by the Mamluk Sultan and the 'Mosque of Sharif bin Hussein bin Ali' that was established in 1975. It is distinguished by wonderful architecture and designs from white stones and by its very high Minaret (Abu Al Haija, 2011). The natural attractions are generally a range of beaches along the coast of Aqaba (Palm Beach, Al-Hafayr Beach, Very-nice Beach, Ghandour Beach) and the diving centers rich with coral reefs (Al-Omari, 2018) (Figure 2).

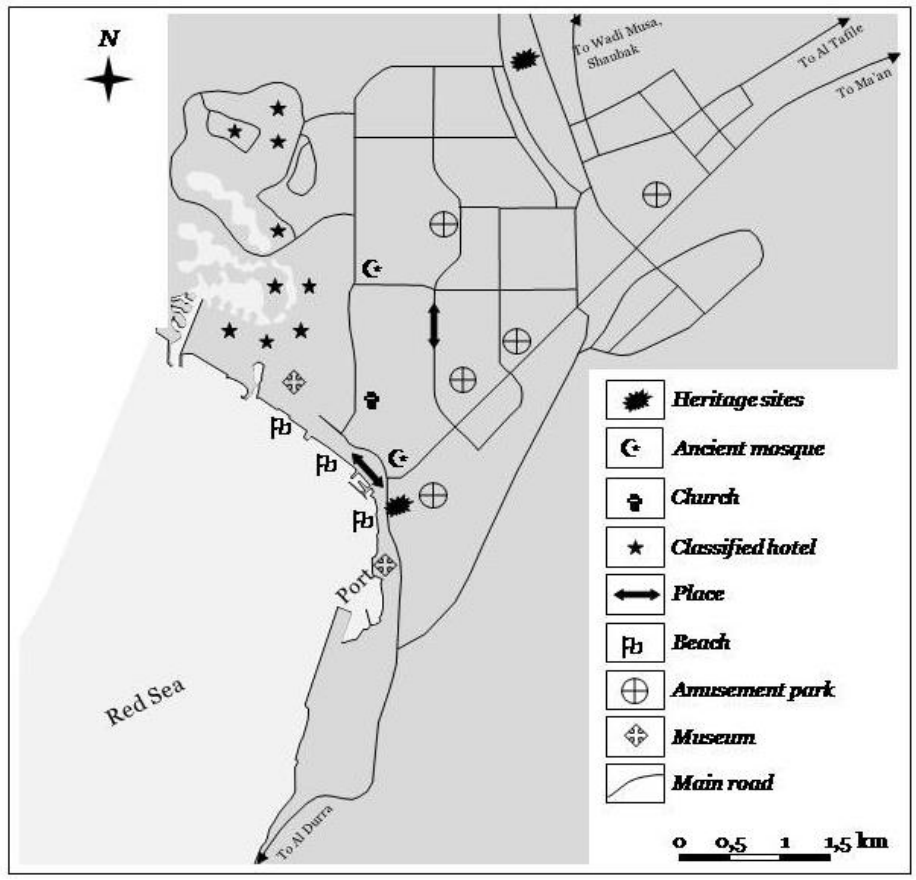

Figure 2. The tourist potential of Aqaba city (Source: Mathieu A., 2013, Field investigation, 2020)

Being important tourist destination, the city of Aqaba witnessed during the first half of 2018, high increase in the number of tourists arriving to Aqaba which reached about 477,322 tourists compared to 306,588 tourists during the same period of 2017 . It is 
worth noting that the foreign tourists constitute $54 \%$ of the total tourists. The Russian tourists top the foreign tourists in the city of Aqaba, followed by French and Polish tourists, while Saudi Arabia leads the first place for Arab tourists. The hotel occupancy rate during the first half of 2018 reached $51 \%$ instead of $49 \%$ during the same period of 2017. The number of nights spent by the tourists in Aqaba reached 3.7 nights compared to 3,4 nights (Economic Policy Council, 2018).

The city of Alexandria, on the Mediterranean coast of the Arab Republic of Egypt, is one of the most important destinations for urban tourism (Jansirani \& Mangai, 2013). It is the second city of Egypt after Cairo, which spans $183 \mathrm{~km}$ to its northwestern direction. It is Egypt's largest port with a population attain the 5,100,000 inhabitants in 2017 (CAPMAS, 2017). The history of the city dates back to more than 5000 years. This has allowed the availability of many tourist areas, such as castles and museums that embody various civilizations: Pharaonic, Greek, Roman and Islamic (Abdelnaby, 2017), represented by the Roman Theater located in the city center, it is one of the most important monuments. The Alexandria Lighthouse and the 'Kayitbay' Citadel, located at the end of Pharos Island in the far west of Alexandria (Darwish, 2018), surrounded by the sea on three sides, giving it an excellent architect view of the Mamluk architecture, the Pillar of the Sowar, it is one of the most famous monuments in Alexandria (Elsorady, 2014). The area of the Muslim cemetery, known as the 'Tombs of the column' and the Koum al-Shakafa archaeological plateau and other monuments that can promote cultural tourism in the city of Alexandria (Aggour, 2017), especially with the presence of about 07 specialized museums: such as the Greco-Roman Museum and the Museum of Royal Jewellery without forgetting the Bibliotheca Alexandrina (UNESCO, 2003). Religious tourism in the city of Alexandria can also be practiced in the presence of the mosque 'Al Morsi Abu Al Abbas', which is one of the most important mosques in the city along with many churches and Jewish shrines. The site of the city of Alexandria is the acquisition of approximately 23 beaches spread along its coast between the Gulf of AbiQar and Agami, and the beaches of: Al-Anfushi, Ibrahimia, Al Maâmora where various marine sports can be practices alongside the Eastern port dedicated to water sports (diving) (Abdel-Salam, 1995).

Despite the fact that Alexandria has multi-tourism potential, it is noted that there has been no increase in the number of hotels in Alexandria which has remained constant in 52 hotels since 1996. This is due to the lack of demand for the establishment of new rooms as occupancy rate of rooms did not exceed $58 \%$ (peak point); this was in 2001 due to the official opening of the library of Alexandria. The number of hotel rooms represented 8.7\% of the total number of hotel rooms in Egypt. The room occupancy rate ranged between 47-53.6\% during 1992-1996 (Ali, 2015), the most famous hotels in Alexandria include: Hilton, Sheraton, Windsor Palace Hotel, Ramada Hotel and Palestine Hotel... (Figure 3). The city has known an increase in the number of tourists coming to it since 1996; their number has increased from 318,000 tourists to 413,000 tourists, while the average tourist duration of stay decreased from 2.2 to 1.8 nights per tourist, the percentage of tourists coming to Alexandria is about $10.6 \%$ of the total tourists coming to Egypt, this percentage is distributed among 22\% of foreigners, $10 \%$ of Arabs and 68\% of Egyptians (El Menshawi \& Eldaidamony, 2017). Studies indicate that the number of tourists is expected to reach 822,000 tourists in 2017, and room occupancy is expected to reach $55 \%$ (Eldaidamony, 2011).

Annaba is the fourth largest city in Algeria (232,533 inhabitants in 2008) (ONS, 2008). It is located on the eastern side of the Algerian coast, within the coral bay, $600 \mathrm{~km}$ from Algiers. It is connected by a dense network of national, highways and railways which link it with the rest of the Algerian cities and with the sites of the natural resources 
(Boukhadra Mines, El Onk Mountain) (Lucette, 1958), in addition to 'Rabeh Bitat' Airport (Tomas, 1977). The city of Annaba has many recreational and entertainment areas that spread within its urban fabric, there also are many historical sites that coincided with the building of the city during the 13th century B.C till present, through the sequence of many civilizations. It is from the Roman city "Hippone" on the banks of Seybouse valley (Cataldo, 1999), to modern Bouna on the mountain of "Aqabet El Ennab" to the Casaba on Mount 'Abed' to Annaba along the western plain stretching along the coastline from the north of the gulf to its south, which reflect the city's heritage and its long history : it is a suitable area to stimulate cultural tourism, especially with the presence of the museum 'Hippone' next to the site of the Roman city. Within the urban fabric of the city of Annaba, many tourist areas spread where tourists find a space for entertainment, recreation and leisure 'Revolution Square'. The center of the city of Annaba, which is adjacent to the old city "La place d'arme", is located to the east and the seaport to the south (Laouar et al., 2019). To the north and west are residential neighborhoods with a European character that host a variety of commercial activities which constitute the center of Annaba (Bensaâd-Redjel \& Labii, 2015). The city embraces ancient mosques, the most important of which are: the 'Abou Merwane' Mosque, the 'El Bey' Mosque, and some corners such as the corner of 'Sidi Brahim Ben El Toumi' and El Zawia 'El Allaweya', as well as 'Saint Augustin' Church which is located in the southern entrance to the city (Derdour, 1982), which allows the practice of religious tourism, as well as beach tourism as there are many beaches from the North to south along Annaba Bay such as 'La Kharoube' Beach, 'Belvedere', 'Chapui, 'Toche', where various coastal sports and diving sports can be practiced (Marikhi, 2010), as well as mountain tourism in the western part of the city, and many species of birds can be seen (Boumaza, 2011). The practice of this type of tourism is encouraged by the presence of the telepark.

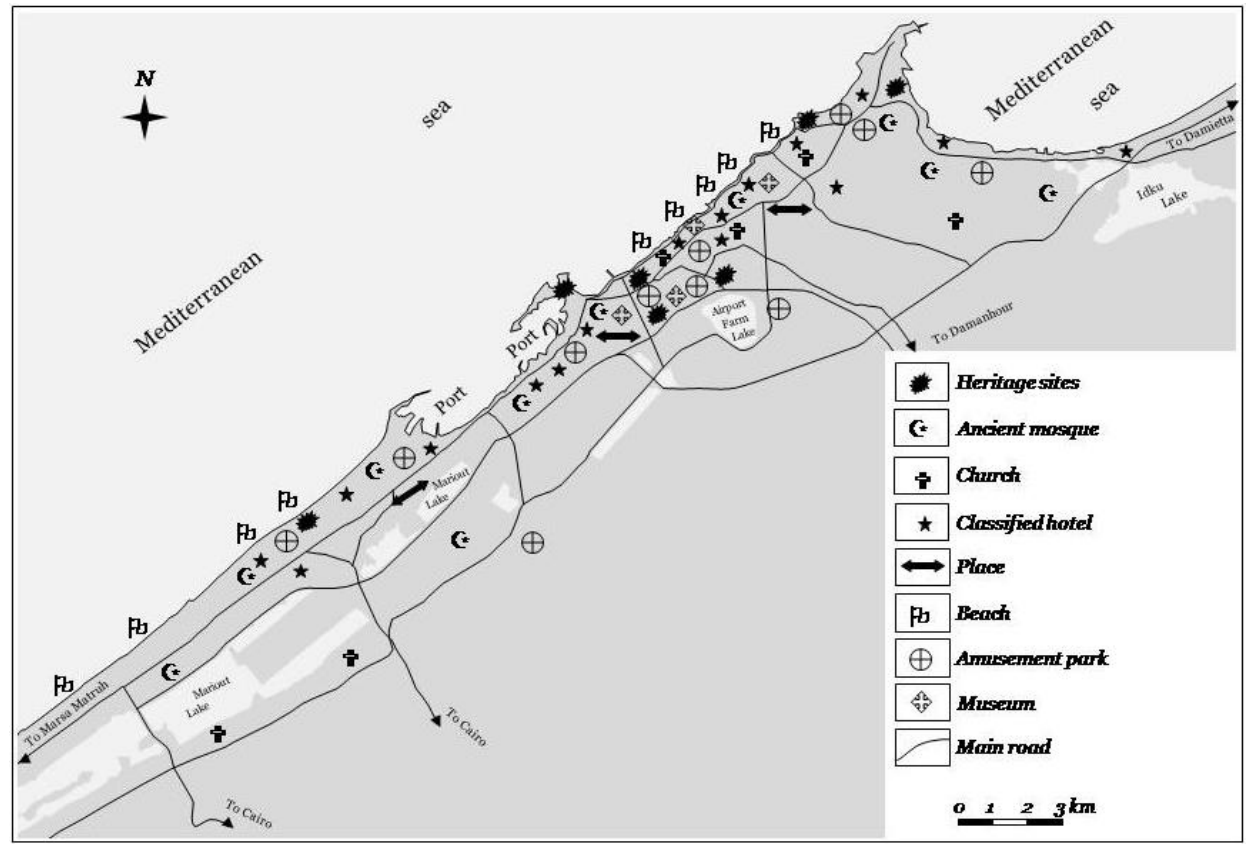

Figure 3. The tourist potential of Alexandria city

(Source: El Menshawi \& Eldaidamony, 2017, authors 2020) 
Regarding the tourism assets: The city of Annaba has a number of world-class hotels in terms of tourism services provided by a total of 29 hotels with a capacity of 2411 beds, namely: Seybouse International Hotel, Sheraton Annaba Hotel, beautiful Reem Hotel, Sabri Hotel (Directorate of Tourism and Traditional Industries of Annaba wilaya, 2017) A number of high-end tourist restaurants such as Orient, Bamako, Carrafal are restaurants that cater traditional meals and dishes. This is a catalyst for prolonging the stay of tourists in Annaba especially to learn about the traditional crafts and crafts of the city in traditional dress and jewelry, as well as the presence of the brain Roll music festivals (music Malouf) and film (Film festival Mediterranean Bouna) (Figure 4).

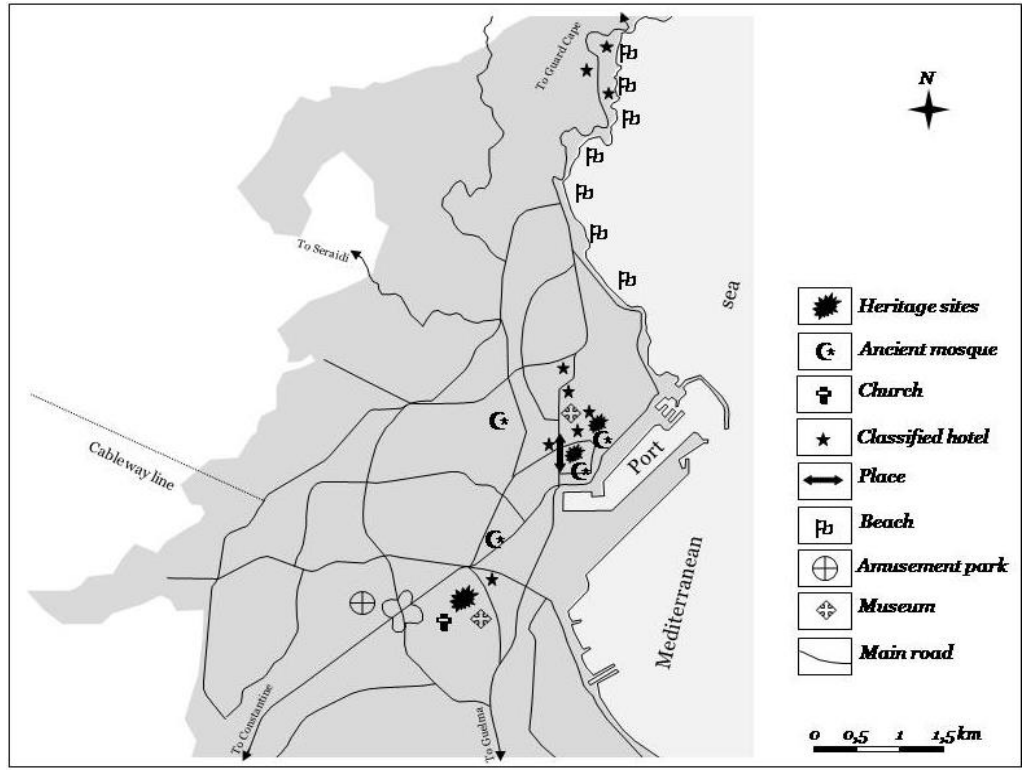

Figure 4. The tourist potential of Annaba city

(Source: URBACO-EDR, 2007, Field investigation, 2020)

The number of tourists who participated in the development of urban tourism in Annaba reached 155,601 tourists in 2016, of whom 18,292 were foreign tourists, or 11.95\%, compared to 9.69\% (Directorate of Tourism and Traditional Industries of Annaba wilaya, 2016). The city of Casablanca is located in Morocco, overlooking the Atlantic Ocean $95 \mathrm{~km}$ south of the capital Rabat, which is the largest city in the country with a population size of 4.270 .750 people in 2014 besides it is the third largest city in Africa after Lagos and Cairo (Zerouali Ouariti \& Hamri, 2014), Casablanca was known as 'Anfa' (Rhinane et al., 2011). Its small harbor was considered as a commercial station for boats coming from the Chaouia plain to obtain barley and wheat, and then the city developed over the years to become the economic and commercial capital of Morocco (Troin, 2002).

The city of Casablanca is famous for its recreational places for urban tourism, the most important of which is the ancient city adjacent to the port, surrounded by the wall and its gate, which allows the visitor to identify the traditional old houses and the old customs of the city, and see the old door of Marrakech, which is the most important door to the old city of Casablanca and the most important symbols of tourism where there are lined up vendors, and the tower "twin" located in the city center is the most important feature of the city of Casablanca. The two high-rise towers consist of 29 floors, which 
include many companies working in the domain of business and attract many tourists from all over the world, especially as they are located near the field (square) 'Mohammed V' (Jabbar \& Bouaouinate, 2014), which is an area of meeting and gathering of tourists from all parts of the world to buy souvenirs from the central market and sit in cafes and enjoy the facades of the hotels, in addition, the city is characterized by the presence of the mosque "Hassan II" that is situated near the old city on the coast of the Atlantic Ocean, the largest religious artefact in Morocco and the seventh largest artefact in the world, which highlights the Moroccan architecture (Troin, 2006), in addition to the Church of 'the Sacred Heart', built in 1930 by the French (Boukherouk, 2017).

On the coastline of the Atlantic there many beaches ranging from the 'Hassan II' Mosque to the beacon of the neck. Here it is worthy to mention the 'Ain El-Dhiab' Corniche, which includes many fine restaurants, cafes, and luxury hotels that attract local tourists (Moroccans) and tourists from all over the world day and night (Barthel, 2010) (Figure 5). The city of Casablanca is characterized by its festivals, which attract a growing number of tourists, that reflect openness and preservation such as the Casa Music Festival, the Urban Music Festival, the Theater and Culture Festival and the International Marathon festival. It is also distinguished by the traditional dress (Coftan), Moroccan ornaments, French and Spanish cuisines are also available through which the Mediterranean dishes are presented (Morocco's National Tourism Office, 2010).

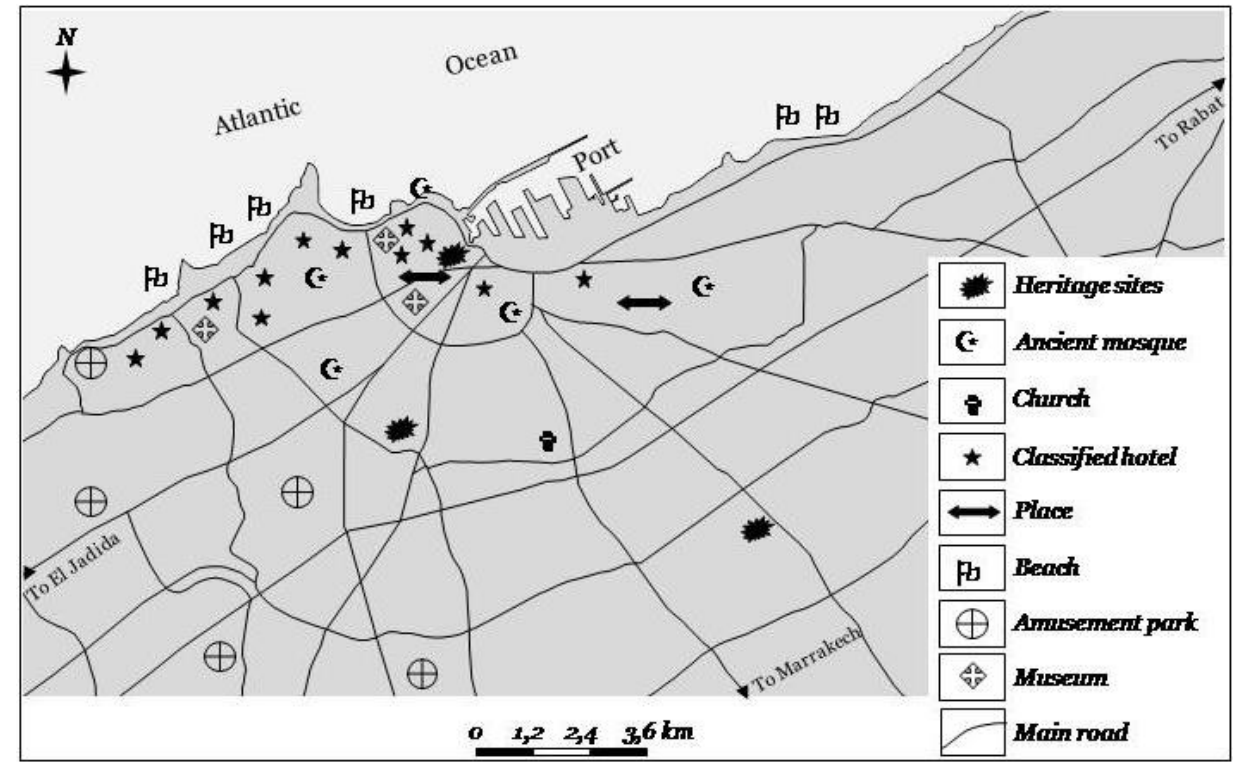

Figure 5. The tourist potential of Casablanca city

(Source: Jabbar \& Bouaouinate, 2014, authors 2020)

In 2016 Casablanca was ahead of all Arab Country, it occupied the fourth place in Africa in terms of visiting tourists, for receiving about 961,694 tourists. While Johannesburg, in South Africa, had topped the list with a total of 4.570.00o tourists. The second place was for Cape Town city with about 1.052.000 tourists. Lagos occupied the third place with about 1.004000 tourists. Where, the fifth place was for Cairo that was visited by about 820,959 tourists (Steenbruggen, 2016). However, the city of Casablanca offers, to all tourists arriving into the city, a wide range of touristic services, including the 
'accommodation services. The city's hotels have about 1,349 rooms distributed over the 22 hotels, which account for $26 \%$ of the hotels in Morocco. (Tourism Observatory, 2013). The number of overnight stays in the Casablanca hotels has increased by $11 \%$, reaching to 1,789,901 overnights in 2017 compared with 1.605.407 overnights in 2016.

The German tourists constituted the significant percentage of tourists, with the highest number of nights in hotels by $24 \%$, followed by Italians and Americans by $23 \%$ for both, while leading the mainland The ranking of hotels in Casablanca was 39\%, followed by American tourists by 33\%, with the number of tourist stays in different accommodation in Casablanca not exceeding two days, over the period between 2010 And 2017 (Tourism Observatory, 2018). This is due to the movement of tourists to other Moroccan cities for the purpose of visit and recreation because the two poles of tourism in Morocco are Marrakech and Agadir, which alone accounted for $60 \%$ of the total number of overnight stays, both destinations increased by $10-8 \%$ respectively, recorded other positive results. The other positive results, especially the cities of Fez (17\%), Rabat (10\%) and Tangier (10\%) (Tourism Observatory, 2018).

Table (01) shows the different places that are practicing urban tourism in the studied Arab Coastal Cities (Aqaba, Alexandria, Annaba and Casablanca).

Table 1. Distribution of Places Practicing Urban Tourism Coastal Cities (Aqaba, Alexandria,

Annaba and Casablanca), (Data source: Treatment of Researchers Based on Many Sources, 2020)

\begin{tabular}{|c|c|c|c|c|c|c|}
\hline $\begin{array}{l}\text { Kariables } \\
\text { Cities }\end{array}$ & Climate & Beaches & $\begin{array}{c}\text { Archaeological } \\
\text { Sites }\end{array}$ & $\begin{array}{c}\text { Public } \\
\text { Squares }\end{array}$ & $\begin{array}{c}\text { Religious } \\
\text { Monuments }\end{array}$ & Museums \\
\hline Aqaba & $\begin{array}{c}\text { Desert climate, } \\
\text { Hot summer, } \\
\text { Mild winter }\end{array}$ & $\begin{array}{l}\text { The coastline } \\
\text { along } 5 \mathrm{~km}\end{array}$ & $\begin{array}{l}\text { - City of 'Aila' } \\
\text { - Aqaba Castle }\end{array}$ & $\begin{array}{l}\text { Spread } \\
\text { along the } \\
\text { coast }\end{array}$ & $\begin{array}{c}\text { - Mosque of } \\
\text { 'Sharif bin } \\
\text { Hussein bin Ali'. } \\
\text { - One church. }\end{array}$ & $\begin{array}{l}\text { Numerous } \\
\text { and } \\
\text { specialized } \\
\text { museums }\end{array}$ \\
\hline Alexandria & $\begin{array}{c}\text { Mediterranean } \\
\text { climate with } \\
\text { hot dry } \\
\text { summer and } \\
\text { mild wet } \\
\text { winter }\end{array}$ & $\begin{array}{c}\text { Heavy spread } \\
\text { of beaches } \\
\text { from 'AbiQar' } \\
\text { to 'Agami' }\end{array}$ & \begin{tabular}{|c|} 
- The city of \\
Maria \\
- Lighthouse of \\
Alexandria. \\
- Roman \\
Theater. \\
- kayitbay castle \\
\end{tabular} & $\begin{array}{l}\text { Many } \\
\text { squares } \\
\text { inside } \\
\text { the city }\end{array}$ & \begin{tabular}{|c} 
- 'Al Morsi Abu Al \\
Abbas' Mosque \\
- Christian \\
Churches. \\
- Jewish \\
attractions \\
\end{tabular} & $\begin{array}{l}\text { Specialized } \\
\text { Museums }\end{array}$ \\
\hline Annaba & $\begin{array}{c}\text { Mediterranean } \\
\text { climate with } \\
\text { hot and dry } \\
\text { summers, cold } \\
\text { winters and wet }\end{array}$ & $\begin{array}{l}\text { There are } 07 \\
\text { beaches from } \\
\text { the top of the } \\
\text { guard to the } \\
\text { mouth of the } \\
\text { Seybous valley } \\
\end{array}$ & $\begin{array}{l}\text { - 'Hippone' } \\
\text { Romanian. } \\
\text { - 'Bouna } \\
\text { Hafsia'. } \\
\text { - The Casbah. }\end{array}$ & \begin{tabular}{|c|} 
Revolution \\
Square
\end{tabular} & $\begin{array}{c}\text { - 'Abou Merwane' } \\
\text { Mosque. } \\
\text {-'El Bey'Mosque. } \\
\text { - The corner of } \\
\text { "Sidi brahim ben } \\
\text { Toumi". } \\
\end{array}$ & $\begin{array}{c}\text { Two } \\
\text { museums }\end{array}$ \\
\hline Casablanca & \begin{tabular}{|c|} 
A mild climate \\
subject to the \\
marine \\
influences in \\
the humidity \\
and wind \\
\end{tabular} & \begin{tabular}{|} 
The beaches \\
extend along \\
the waterfront \\
of the 'Ain al- \\
Dhiab'
\end{tabular} & \begin{tabular}{|l|} 
- The old city \\
"Anfa". \\
- The ancient \\
door of \\
Marrakech. \\
- Twin Tower. \\
\end{tabular} & $\begin{array}{l}\text { Mohammed } \\
\text { V' Square }\end{array}$ & $\begin{array}{l}\text { - Mosque of } \\
\text { 'Hassan II'. } \\
\text { - Church of the } \\
\text { 'Sacred Heart'. }\end{array}$ & Museums \\
\hline
\end{tabular}

\section{CHALLENGES AND PROSPECTS OF URBAN TOURISM DEVELOPMENT IN COASTAL CITIES}

The four cities comprising the study cases face many challenges in order to achieve urban tourism development, mainly related to the development strategies adopted by each city. Aqaba is the only Jordan's port to the outside world, and area of economic 
exchanges because of the port. It is also a commercial and tourist center, and plays a large role in the city's economy. About half of the workforce of Aqaba works in the Port. They work in the loading and unloading, transport and storage. The construction sector comes in the second, and then followed by the industrial sector in the third place, where the industrial zone was constructed at the south of the port included fertilizers, timber and mining factories port. The services sector, including tourism, restaurants, hotels and trading ranked fourth of the total labor force, while the sector of fishing and agriculture activities declined at present, their importance diminished due to the change occurred to the city economic function (Abu-Ghazalah, 2008). It is worth mentioning that the port of Aqaba witnesses an active movement, it receives more than 2500 vessels annually. The volume of exported and imported goods exceeds 125 million tons per year. The passengers' traffic port is also active. The number of passengers arriving and departing through the port exceeds one million passengers per year (Buda, 2016).

The Aqaba Special Economic Zone Authority (ASEZA) has directed the development of the tourism sector and other economic sectors, especially the heavy industries, within its development strategy by applying the strategy of transforming Aqaba into an internationally recognized tourist destination within a highly competitive regional system, Tabah and Nuweiba (Mathieu, 2013). Many studies have reached that, despite the multiple potentials that qualify the city of Alexandria (Sirry, 2007), there is a decline in tourism development in city, especially with the emergence of resorts and tourist villages on the Red Sea Coast, where the international tourism movement had stopped, and tourism was confined to domestic tourists and to the Arab tourists. This decline in development is due to a number of administrative and financial obstacles. However, one of the future aspirations is the work to restore tourism movement, that was reached during 2010 (Ragheb et al., 2016). Pointing out that Egypt recorded during that year a tourism movement of about 14 million tourists while it has been increasinguntil 2018, when it achieved 9 million tourists. This was supported by the establishing of an integrated leisure city to be a tourist and leisure center and therapeutic touristic center.

In addition, there is the 'Al-Alamein' project (Hussien, 2017), which is hoped to be a core (center) for a number of other touristic projects. In an attempt to developing Beach Tourism, cultural Tourism and therapeutic tourism in Alexandria, especially with the availability of the natural and human factors and the necessity to exploit such factors, within a strategic plan capable of bringing together all these various factors, in particular the foreign investors (El Menshawy et al., 2011). Annaba city, in order to achieve comprehensive economic development, adopted during the 1970's the industrialization policy, resulted in the settlement of the most important industrial compounds in Annaba city, namely 'ElHadjar' complex for iron and steel, 'Asmidal' compound for nitrogenous and Phosphate fertilizers, and a heavy spread of industrial units in four industrial zones and even within the city's urban fabric, where all industrial settlement factors (port, railways, highways, international airport, labor, raw materials, water) are available (Benghadbane, 2017).

During the last few years, in order to promote the tourism sector, the tourism development plan for preparing tourism for the horizons of the 2030 has been found. The city of Annaba is one of the tourism excellence poles, which allowed it, as part of a tourism development strategy, to benefit from many tourism programs. Some of them on the city level, these programs assess the potential of tourism development by involving various actors, including enhancing accommodation capacity by more than 2500 new beds, by receiving projects in progress that have reached about $70 \%$ renovating, such as the 'Orient' Hotel overlooking the 'Revolution' Square after completion of restoration work, which represents an architectural masterpiece and services geared towards the development of 
urban tourism and business tourism. Urban tourism is also reinforced by the reopening of the Hotel 'El-Hoggar" in 'George Ishac' Square after similar renovations and rehabilitation.

In addition to launching of the modernization and rehabilitation program of the hotel 'Seybouse' International, which represents the first urban and modern hotel opened in Annaba in 1975 with a capacity of 518 beds as a 5 star hotel equipped with luxury dining suites and leisure, entertainment spaces, shopping and other business and services in international standards, also in the framework of this strategic program will also start rehabilitating and modernizing the Park 'El Mountazah' in Seraïdi municipality, which was built in 1971 with a capacity of up to 202 beds ; the physical education and rehabilitation center 'Craps' in Seraïdi will be reopened in the next few months. The two tourist expansion areas of Seraïdi and Chetaïbi municipalities were also supported by 18 tourism projects, combining hotels, tourist residences, chalets and programmed tourist vehicles (Directorate of Tourism and Handicrafts of the Wilaya of Annaba, 2017). Annaba, with its numerous qualifications, is steadily moving towards the developing of many activities of promoting tourism, through the emerging of clubs with environmental activities, such as the 'Fly by Parachutes' club and the 'Seraïdi Adventures", which attract many young people from inside and outside the country, to participate in sports entertainment and tourism promotion courses across Mount Edough (URBACO-EDR, 2007).

Regarding to Casablanca city, there are future aspirations to promote touristic development in the city (Berriane, 2002). This can be done through a project to develop the sea port, by transferring a part of it from commercial to touristic activities, funded by the Gulf Investment Fund (Wesal Capital). Also new other developing projects will be initiated in different areas of the city, which include the establishing of a new urban center and the renovating of the traditional old city, and the rehabilitating of the touristic coastline, and promoting the city as a pioneering destination for the cultural tourism, business tourism and maritime voyages (Moroccan National Tourist Office, 2016).

The city also hopes to promote both family tourism and eco-tourism, through the participation of various partners and investors from the UAE, Gulf, Arab and Asian countries, under the slogan 'YougoMorocco 2018', who presented many development options in the framework of Arab cooperation, in order to develop the touristic investment tools and to promote the Moroccan touristic destinations so as to attract the Arab tourists from the Middle East and the Arabian Gulf to develop the sector of tourism in Casablanca city, and from there to all the Moroccan cities (Moroccan National Tourist Office, 2016).

\section{RESEARCH RESULTS}

The coastal Arab cities offer important touristic destinations to promote tourism development, which were varied levels in accordance with the development strategy adopted in each city. Therefore, the analysis of the various coastal touristic destinations in the four cities (Aqaba, Alexandria, Annaba and Casablanca) to reach to the following results:

- The four cities occupy strategic geographical locations in the focus of the international tourism, supported by their acquisition of important maritime ports (commercial and tourist activities) and international airports to attract tourists from different regions and nationalities.

- The Arab coastal cities, in their different geographical locations, whether in the Arab East or North Africa, possess much natural, historical and urban potential that represent areas of recreation and entertainment, and allows the practicing of many types of coastal, cultural, religious, therapeutic and urban tourism and promote the development of tourism in those cities. 
- The geographical origin of the tourists coming to each Arab coastal city is varied, whereas to Annaba city arrive tourists from Algeria (local) in high ratios compared with foreigners who represent the nationalities of European countries (French, Russian, Italian), while to the city of Alexandra, most of the tourists are local (Egyptians) and some Arab nationalities, while the cities of Aqaba and Casablanca, the majority of tourists are foreign tourists who make up many nationalities.

- Seasonal tourism variably dominates the touristic market of the four studied cities. The seasonality is marked by the absolute dominance of the city of Annaba, which is active in beach tourism during the summer, and to a lesser extent in the city of Alexandria. In the city of Casablanca, seasonality is absent, as the tourism activity continues all the tourist season. This city constitutes a transit to other Moroccan tourist cities (Marrakech, Fez, and Tangier). The city of Aqaba is working to overcome the seasonal phenomenon by setting a strategic plan for tourism development within the framework of the Golden Triangle: Aqaba, Wadi Rum and Petra.

- All the four cities, subject of the study, suffer from the deterioration in their environmental system due to the pollution resulting from industrial settlement, especially the cities of Annaba and Casablanca, which are witnessing the intensification of the industrial units and heavy industry vehicles, where this pollution affected the air, water and soil, as a result of dumping industrial waste and accumulation, whereas the city of Alexandria is less affected by the pollution meanwhile the industrial pollution hit the coastline as well as 'Mariout' Lake. The city of Aqaba has a low pollution rate due to the lack of industrial activity compared to the previous three cities.

- The four mentioned cities are characterized by chaotic housing and slums, due to the intensive industrialization these cities have witnessed, in the framework of their economic and social development strategy, which was more severe in the city of Casablanca, where the slums cover large areas, next to it is the city of Alexandria. Whereas the city of Annaba has been disposed of the pockets of chaotic housing by providing adequate housing, as part of its development strategies, for all residents of the city, while Aqaba is considered almost free of slums.

- The historical and archaeological areas and monuments in the four cities are located within the urban fabric, between the residents' dwellings, which form a barrier in the face of constructing wide roads to enable the tourists reach to, and connect these locations to the rest of the recreation and entertainment locations in these cities.

- The lack of green areas and meeting places, especially in the city of Aqaba, followed by Alexandria, then the city of Casablanca and the city of Annaba.

- The lack of interest in the traditional industries, and the lack of awareness to the necessity of the community's participation in the development of tourism. This seems more evident in Annaba city and to a lesser extent in Alexandria city, but in the cities of Aqaba and Casablanca there are efforts to spread cultural awareness among the local community.

- In all four coastal cities, there is an interest in developing the touristic services, especially in providing reception structures and hotels, that there is constantly increasing, except in the city of Alexandria where the number of hotels has remained constant since the nineties; but what draws the attention is the high cost of accommodation in these hotels which has its impact on the low index duration of stay.

- In each of the four cities, there is a difficulty in the movement of tourists between the touristic destinations, because of their lack of connection to the 
transport, which already suffers from congestion and high fare. Therefore, these cities will continue to suffer from the problems of transport and traffic, which constitute the greatest obstacles in attracting tourists.

Table 2 shows the most important characteristics of urban touristic development in the Arab coastal cities: Aqaba, Alexandra, Annaba and Casablanca).

Table 2. Most important characteristics of urban touristic development in the coastal cities

(Aqaba, Alexandra, Annaba and Casablanca), (Data source: Researchers Study, 2020)

\begin{tabular}{|c|c|c|c|c|c|c|c|c|c|c|}
\hline Zariables & $\begin{array}{l}\text { Geographic } \\
\text { Origin of } \\
\text { arriving } \\
\text { tourists } \\
\end{array}$ & $\begin{array}{l}\text { Season. } \\
\text { Degree }\end{array}$ & $\begin{array}{l}\text { Environ. } \\
\text { Deterio } \\
\text {-rating } \\
\text { Degree } \\
\end{array}$ & $\begin{array}{l}\text { Slums } \\
\text { Spread }\end{array}$ & $\begin{array}{c}\text { Infra- } \\
\text { structure }\end{array}$ & $\begin{array}{l}\text { Ultra- } \\
\text { Struc- } \\
\text { ture }\end{array}$ & $\begin{array}{c}\text { Reaching } \\
\text { Tourist } \\
\text { attract- } \\
\text { tions }\end{array}$ & $\begin{array}{l}\text { Green } \\
\text { areas } \\
\text { in city }\end{array}$ & $\begin{array}{c}\text { Trans- } \\
\text { port }\end{array}$ & $\begin{array}{l}\text { Commu- } \\
\text { Nity } \\
\text { partici- } \\
\text { pation }\end{array}$ \\
\hline Aqaba & \begin{tabular}{|c|}
$15 \%$ Local \\
$85 \%$ Foreign \\
from different \\
countries
\end{tabular} & $\begin{array}{l}\text { Very } \\
\text { weak }\end{array}$ & Weak & $\begin{array}{c}\text { Semi } \\
\text { total } \\
\text { absence }\end{array}$ & $\begin{array}{c}\text { Highly } \\
\text { developed }\end{array}$ & $\begin{array}{l}\text { Very } \\
\text { Good }\end{array}$ & Easy & Weak & Good & $\begin{array}{l}\text { Encou- } \\
\text { raged }\end{array}$ \\
\hline Alexandria & \begin{tabular}{|c|}
$80 \%$ Local \\
$20 \%$ Arab \\
Tourists \\
\end{tabular} & High & Average & High & Average & Average & Difficult & Average & Average & $\begin{array}{c}\text { Starting } \\
\text { Sprea- } \\
\text { ding }\end{array}$ \\
\hline Annaba & \begin{tabular}{|c|}
$85 \%$ Local \\
$15 \%$ Foreign \\
Tourists
\end{tabular} & $\begin{array}{l}\text { Very } \\
\text { high }\end{array}$ & $\begin{array}{l}\text { Very } \\
\text { high }\end{array}$ & Weak & Average & Good & Average & Average & Average & $\begin{array}{c}\text { Semi } \\
\text { Total } \\
\text { absence }\end{array}$ \\
\hline Casablanca & $\begin{array}{c}15 \% \text { Local } \\
85 \% \text { Foreign } \\
\text { Tourists }\end{array}$ & Weak & $\begin{array}{l}\text { Very } \\
\text { high }\end{array}$ & $\begin{array}{l}\text { Very } \\
\text { high }\end{array}$ & Developed & $\begin{array}{l}\text { Very } \\
\text { Good }\end{array}$ & Easy & Weak & Good & $\begin{array}{l}\text { Interested } \\
\text { in Partici- } \\
\text { pation }\end{array}$ \\
\hline
\end{tabular}

\section{RESEARCH RECOMMENDATIONS}

In light of the above-mentioned, some recommendations can be included to promote urban tourism development in tourist cities, including:

- The necessity of implementing urban touristic development plan, in the cities subject of this study, each city individually, taking into account the interests of the local population on one hand, and fulfilling the tourists" aspirations in leisure and recreation in the urban touristic destinations.

- Identifying the roles and responsibilities when adopting a rational management of urban tourism, combining the characteristics of touristic destinations and the urban planning.

- The necessity of involving the various actors, especially the urban population, when programming of urban tourism projects.

- Encouraging the traditional crafts and industries, and display them to the tourists in a way that the social and economic benefits may be obtained out of them. This can be by organizing exhibitions, festivals and markets in the touristic cities, which facilitate good relationship between local people and tourists.

- Completing the construction of classified four and five-star hotels in the cities of Annaba and Alexandria in order to ensure providing high-quality touristic services for foreign tourists, to increase their number and increase the number of touristic night-stay.

- Investing in the historical and archaeological buildings, by equipping and preparing them, to provide a distinctive touristic presentation for the old cities and lighting them, especially the city of Annaba, and the recruitment of touristic guides to introduce them, which would encourage the expansion of such touristic investments to all heritage areas. 
- Establishing of classified restaurants in the old cities after their maintenance, and offering of traditional cuisine in such restaurants.

- Conducting awareness campaigns to introduce the importance of urban tourism in all studied cities, through giving the classes and lectures by specialists in the field, directing these campaigns to the youth group, in order to clarify the relationship between the city and tourism,

- Developing an efficient and strict traffic plan that may connect and reach to various touristic destinations, taking into account the allocating of corridors and roads between patrols and vehicles.

- Regulating the anarchic trade in a way that would develop traditional crafts and industries.

- Rehabilitating and prequalifying the waterfront of Annaba city to be a touristic destination on the national, Maghreb and Mediterranean levels, suiting their geographical location, appropriate to the presence of the port and Mount Edough, that would give them the distinctive style of the Mediterranean cities and make them future significant touristic destination.

- Developing renewed plans to promote the potentials of urban tourism in each city, in line with the available financial resources, taking into account the requirements of the touristic market at different spatial levels, starting from local (domestic) marketing before the international, taking into account the entity and category to be targeted.

- Spreading the culture of tourism and awareness of tourism among the various doers, especially the residents of Annaba, encouraging them to participate and work within the plan of tourism promotion, as a local community capable of developing the traditional industries (crafts) that directly contribute to touristic development.

- The necessity of overcoming the phenomenon of seasonal tourism, by stimulating, in the studied cities, the practice of all types of tourism (beach, cultural, sports, mountain) so long as they are cities similar in their acquisition to many different touristic potentials.

- Encouraging the sustainable urban tourism, that attempts to achieve urban ecological balance, to ensure the welfare of the population and tourists alike.

- Compelling the industrial establishments in the entire cities subject of the study, to take all precautionary measures in order to limit the pollution phenomenon, especially by initially treating of waste before disposal, and to encircle all industrial areas with a green belt (trees), and furnishing the green spaces in all cities.

- Providing various investment incentives in Annaba city to integrate the private sector as a key partner in the development of urban tourism, especially fees, taxes, and banking facilities... in order to expedite completing of various touristic projects.

- Benefiting from the experience of the city of Aqaba in a rational manner, in the development of the tourist city of Annaba, in line with the particularity of the Algerian tourism market.

- Promoting urban tourism in Alexandria to return the city back to its former tourist status in the Mediterranean basin.

- To continue the touristic development in the two cities of Aqaba and Casablanca, and to encourage the digital tourism in them; and work to upgrade the two cities to international tourist cities, especially as they enjoy important locations in the international touristic movement. 


\section{CONCLUSION}

This study points out the importance of developing urban tourism in the coastal cities, clearly among the four Arab cities studied: Aqaba, Alexandria, Annaba and Casablanca, despite the convergence recorded in the potential of urban tourism, but there are obvious paradoxes, where coastal tourism dominates as the prominent type of tourism in city of Annaba and cultural tourism in the cities of Alexandria and Casablanca, while most of the types of tourism in the city of Aqaba, and these cities suffer from many obstacles highlighted in the seasonal tourism, and the emergence of pollution as a result of industrial activity that competes with tourism in these cities (Infrastructure, natural resources, labor), as well as the weakness in some tourism services, particularly in the hotel sector, that are required to develop some strategies to remedy this situation so that the urban tourism be promoted through the multitude of touristic projects, the investment opportunities and employment opportunities, based on continuously renewed promotion ways and methods on various internal and international levels, through which the largest number of tourists from specific and targeted categories, is attracted to increase their revenues; supported by a number of incentives, to occupy a distinguished position in the international touristic market which is supported through its geographic location.

\section{REFERENCES}

AbdelNaby, H. (2017). Problems and challenges of cultural heritage in Alexandria, Egypt. International Journal of Culture and History, 3(3), p. 174-178.

Abdel-Salem, H. (1995). The historical evolution and present morphology of Alexandria, Egypt. Planning perspectives, 10(2), p. 173-198.

Abu Al Haija, A. (2011). Jordan: Tourism and conflict with local communities. Habitat International 35, 93-100.

Abu-Ghazalah, S. (2008). The Sustainable City Development Plan for Aqaba, Jordan. Journal of Developing Societies, 24(3), p. 381-398.

Aggour, H. (2017). Virtual reality: towards preserving Alexandria heritage by raising the awareness of the locals. International Journal of Architectural Research, 11(3), p. 94-108.

Alananzeh, O.A., Al-Badarneh, M., Maaiah, B. \& Al-Mkhadmeh A. A. (2018). The effect of hotel attributes on length of stay and hotel choices in coastal cities: Aqaba as a case study. Dirasat: Human and Social Sciences, 45(4), p. 275-289.

Ali, W.H. (2015). Indicators for Sustainable Development Strategies and Components of Tourism Regions in Egypt A Study of Alexandria and the Northwest Coast. International Journal of Environmental Protection and Policy, 3(2), p. 39-52.

Al-Nasarat, M. (2012). Byzantine maritime trade in southern Jordan: The evidence from port of Aila ('Aqaba). Mediterranean Arhaeology and Archaeometry. 12(1), p. 101-116.

Al-Omari, B.M. (2018). Tourism sector development in Jordan constituents, challenges and requirements. Journal of Tourism \& Hospitality, 7(6), p. 1-16.

Al-Saad, S., Al-Orainat, L., Al-Badarneh, M. \& Al-Makhadmeh, A. (2018). Residents' Perceptions towards Tourism and its Impacts on their Quality of Life in Aqaba City, Jordan. Dirasat: Human and Social Sciences, 45(1), p. 229-244.

Al-Saad, S. \& Ababneh, A.K. (2017). Concept, opportunities and challenges of urban tourism in the Arab world: Case studies of Dubai, Cairo and Amman. Tourism Review: An International Interdisciplinary Journal. 65(3), p. 361-375.

Amira, A.M. (2011). Building a marketing information system for tourist sites in Aqaba Governorate using ArcGIS 9.3. Master of Business Administration, Middle East University, Jordan, p. 108.

Ashworth, G. \& Page, S.-J. (2011). Urban tourism research: Recent progress and current paradoxes”, Tourism Management, 32, p. 1- 15 .

Ashworth, G. (2003). Urban tourism: still an imbalance in attention? In C. Cooper (Ed.), Classic reviews in tourism (p. 143-163) Clevedon: Channel View.

Attaallah, F. \& Al-Ehewat, N. (2014). Evaluating Study for Elements Affecting Tourism Awareness in Jordan: Applied on Aqaba and Wadi Rum Areas. Global Review of Research in Tourism, Hospitality and Leisure Management, 1(1), p. 58-71.

Bader, M., Alrousan, R., Abuamoud, I. \& Abu- Alasal, H. (2016). Urban Tourism in Jordan: Challenges and Opportunities, Case Study: Amman. British Journal of Economics, Management \& Trade, 12(4), p. 1-11. 
Barrera-Fernández, D., Hernández-Escampa, M. \& Balbuena, A. (2016). Tourism management in the historic city.The impact of urban planning policies. International Journal of Scientific Management and Tourism, 2(4), p. 349-367.

Barthel, P.A. (2010). Casablanca-Marina : un nouvel urbanisme marocain des grands projets, Presses de Sciences Po, Autrepart, 55 (3), p. 71-88.

Benghadbane, F. \& Khreis, S. (2019). The role of tourism marketing in enhancing tourism development: a comparative study between Constantine and Amman cities. GeoJournal of Tourism and Geosites, 24(1), p. 146-160.

Benghadbane, F. (2017). The Geographic Information Systems (GIS) Application in the Evaluation of Sanitary Services in the Big Algerian Cities Empirical Study on the City of Annaba. Journal of Remote Sensing \& GIS, 6, p. 1- 7.

Bensaâd-Redjel, N. \& Labii, B. (2015). Alignement et extension: des plans pour Bône : Eléments sur l'application de l’urbanisme à la française en Algérie : 1855 et 1932-1933. Cahiers de géographie du Québec, 59(166), p. 109 -133.

Berriane, M. (2002). Les nouvelles tendances du développement du tourisme au Maroc http://xxi.ac-reims.fr/ fig-st-die/actes/actes_2002/berriane/article.htm.

Blaževic, B. \& KrstinicNižic, M. (2015). City organization as urban challenge for tourism destinations. Tourism in Southern and Eastern Europe. 3rd International Scientific Conference Tourism in Southern and Eastern Europe. Tourism in Southern and Eastern Europe, 3, p. 19-33.

Bock, K. (2015). The changing nature of city tourism and its possible implications for the future of cities. European Journal of Futures Research, 20(3), p. 1-8.

Boumaza, M. (2011). Edough: mystic and fabulous country of Ouichaoua, Imprimerie PHENIX Color, Annaba, Algeria, p. 160.

Boukheroukn, M. (2017). Yachting - Nautical Tourism in the 2020 Moroccan Tourism Strategy: An Analysis of the Models of Saïdia and Bou-Regregmarinas. Athens Journal of Tourism, 4(4), p. 307-334.

Buda, D.M. (2016). Tourism in Conflict Areas: Complex Entanglements in Jordan. Journal of Travel Research, 55(7), p. 835-846.

Cataldo, H. (1999). Bône of my youth 1935- 1962, Edition Gandini, Nice, France, p. 188.

Cave, J. \& Jolliffe, L. (2012). Urban Tourism. Tourism: The Key Concepts, Robinson, P. (Ed.) London: Routledge, p. 268-270.

Darwish. M.A. (2018). Development of architectural planning of pharos castle, Alexandria. International Journal of Academic Multidisciplinary Research, 2(10), p. 46-61.

Derdour, H. (1982). Annaba-25 centuries of daily life and struggles, 1, SNED, Algiers, p. 380.

Dharmwani, L. (2013). Tourism in Rajasthan: Challenges and Opportunities, Indian Journal of Applied Research, 11(3), p. 63-64.

Eldaidamony, M. (2011). Urban Tourism and Strategic Planning: An Integrated Study of Alexandria and Barcelona, UNICA Euromaster in Urban Studies 4Cities. Vrije Universiteit Brussel, p. 105.

El Menshawy, A., Sharaf Eldin, S. \& Fekry, F. (2011). Creating a tourism destination through sustainable development: case study coastal area of Abuqir, Alexandria, Egypt. WIT Transactions on Ecology and The Environment, 167, p. 423- 434.

El Menshawi, A. \& Eldaidamony, M. (2017). Introducing urban tourism in Alexandria and Barcelona: An integrated study of Alexandria and Barcelona, SSRN Electronic Journal, p. 1-12.

Elsorady, D.A. (2014). The economic value of heritage properties in Alexandria, Egypt, International journal of heritage studies, 20(2), p. 107-122.

Estelaji, A., Sadeghian, H. \& Beyhaghi, Z.. (2012). The role of urban tourism to achieve urban sustainable development. International Journal of Geology, 6(1), p. 17- 25.

Gârbea, R.V. (2013). Urban tourism between content and aspiration for urban development. Management \& Marketing, XI(1),p. 193- 201.

Griffin, T. \& Hayllar, B. (2009). Urban tourism precincts and the experience of place. Journal of Hospitality Marketing and Management. 18(2-3), p. 127-153.

Hashemite Kingdom of Jordan, (2016). Jordan in Figures, Amman, Jordan: Department of Statistics, p. 183.

Hakeem, A. \& Khan, H. (2018). Urban Tourism: the Perspective on Tourism Impacts in Cambridge, United Kingdom. Marketing and Management of Innovations, 24(3), p. 268- 275.

Hussien, A. (2017). New El Alamein: A New Path for Investment in Egypt. Murabahat: Real Estate Solutions (5 June 2017), p. 23.

Hayllar, B., Griffin, T. \& Edwards, D. (2008). City Spaces - Tourist Places: Urban Tourism Precincts. Butterworth-Heinemann is an imprint of Elsevier: Oxford- UK, Burlington: USA, p. 400.

Jabbar A.R. \& Bouaouinate A. (2014). The old Medina of Casablanca: a diverse cultural and tourist wealth that is poorly exploited. Master thesis 'Rural and cultural tourism', Hassan II University, Mahamadia, Morocco, p. 107.

Jansirani, S. \& Mangai, L. (2013). IndustrialTourism: An Introduction. Journal of Business and Management, 9(4), p. 12-14.

Jiménez, J.L., Nombela, G. \& Suárez-Alemán, A. (2017). Tourist municipalities and local political corruption. International Journal of Tourism Research, 19(5), p. 515-523.

Khreis, S. (2016). Perception of Aqaba residents in Jordan towards the impact of tourism. Journal of College of Tourism and Archeology, 27(2), p. 1-13.

Kidane-Mariam, T. (2015). Ethiopia: Opportunities and Challenges of Tourism Development in the Addis Ababa-upper Rift Valley Corridor. Journal of Tourism and Hospitality, 4, p. 1- 9. 
Lucette, T. (1985). Bône. The formation of the city and the factors of its evolution. Annals of Geography, 67(364), p. 498-520.

Laouar, D., Mazouz, S. \& Teller, J. (2019). Spatial accessibility and urban fragmentation in colonial cities: The case of Annaba city. Cybergeo: European Journal of Geography, Aménagement, Urbanisme, document 884. DOI : $10.4000 /$ cybergeo.31539

Marikhi, Y. (2010). Environmental balance and the Sustainable Tourism Development of Annaba wilaya.Master's Thesis in Regional planning, Faculty of Earth Sciences, Geography and Urban Design, University of Constantine, Algeria, p. 181.

Mathieu, A. (2013). Aqaba: an Extra-Territorial city, p. 407-401; Ababsa, Meryem (coordinator), Atlas of Jordan: History, territories and society, Ifpo Press, Publications of the French Institute of Middle East.

Murillo, J., Vayá, E., Romaní, J. \& Surinach, J. (2013). How important to a city are tourists and day-trippers? The economic impact of tourism on the city of Barcelona.Tourism Economics, 19(4), p. 897-917.

Maxim, C. (2016). Sustainable tourism implementation in urban areas: A case study of London. Journal of Sustainable Tourism, 24(7), p. 971- 989.

Nogués-Pedregal, A.M. (2019). The instrumental time of memory: local politics and urban aesthetics in a tourism context. Journal of Tourism Analysis. https://doi.org/10.1108/JTA-05-2018-0014

Postma, A., Buda, D.-M. \& Gugerell, K. (2017). The future of city tourism. Journal of Tourism Futures, 3(2), p. 95-101.

Ragheb, Gh., El-Shimy, H. \& Ragheb, A. (2016). Land for Poor: Towards Sustainable Master Plan for Sensitive Redevelopment of Slums. Procedia - Social and Behavioral Sciences, 216, p. $417-427$.

Romero Renau, L. (2018). Touristification, Sharing Economies and the New Geography of Urban Conflicts. Urban science, 104(2), p. 1- 17.

Sirry, A. (2007). Cultural heritage sites and the challenges of urban development; the dilemma of old cities, planning in risk society.xxi Aesop conference, Napoli, p. 145-158.

Shiji, O. (2017). Urban tourism: The case of India. International Journal of Advanced Education and Research, 2(6), 30-36.

Steenbruggen, J. (2016). Tourism Geography: Emerging Trends and Initiatives to Support Tourism in Morocco. Journal of Tourism \& Hospitality, 5(3),1-16.

Tomas, F. (1977). Annaba et sa région, organisation de l'espace dans l'extrême- Est Algérien, Thèse de Doctorat, université Saint-Étienne, France, p. 720.

Troin J.F. (dir.), (2002). Maroc : Régions, Pays, Territoires, Maisonneuve et La Rose, Paris, p. 502.

Troin J.F. (dir.), (2006). Le grand Maghreb. Mondialisation et construction des territoires, Paris, Armand Colin, p. 384.

Valls, J.F., Banchini, S., Falcón \& L.,Tuñon, G.V. (2013). Repositioning of Barcelona's Image in the Light of a Redefinition of the Urban Tourism Planning Model.Revista de Turismo y Patrimonio Cultural, 11(1), p. 89-105.

Vles, V. (2011). Entre redynamisation urbaine et banalisation des espaces : tensions et enjeux de l'urbanisme touristique. Mondes du Tourisme, 3, p. 14- 25.

Van Den Berg, L., Van Der Borg, J. \& Van Der Meer, J. (1995). Urban Tourism: Performance and Strategies in Eight European Cities. UK: Ashgate. P. 226.

Wu, C., Mandabach, K.H. \& Hertzman, J.L. (2018). Measuring of Land Use Conflict: A Coastal Tourism Destination Case Study. Journal of Tourism \& Hospitality, 7(4), p. 1-7.

Yildiz, S. \& Akbulut, M.T. (2013). Current trends in developing urban tourism.International Journal of Architectural Research, 7(2), p. 297-310.

ZeroualiOuariti, O. \& Hamri, H.M. (2014). Business tourism towards improving the tourism offer in morocco: case of seaside town of Agadir. International Journal of Business Tourism and Applied Sciences, 2(2), p. 8-16.

*** CAPMAS, ( 2017). National Census book for population and buildings http://www.capmas.gov.eg/

*** Directorate of Tourism and Traditional Industries of Annaba wilaya. (2017). Annual Report, Annaba, Algeria, p. 73.

*** Directorate of Tourism and Traditional Industries of Annaba wilaya. (2016). Annual Report, Annaba, Algeria, p. 67.

*** Economic Policy Council, (2018). Jordan: Economic Growth Plan 2018 - 2022. Amman, Jordan, p. 116.

*** Morocco's National Tourism Office, Casablanca in Morocco, 2010. www.visitmorocco.com

*** Moroccan National Tourist Office (2016). Casablanca, Morocco: a new spatial sign, Morocco, p. 37.

*** ONS: National Office of Statistics (2011). The urban frame RGPH 2008: The main results of the exhaustive exploitation. National Office of Statistics, Algiers, p. 213.

*** Tourism Observatory, (2013). Statistical yearbook. Morocco. (www.observatoiredutourisme.ma).

*** Tourism Observatory, (2018). Statistical directory of tourism, overview of tourism performance for 2017, Ministry of Tourism, p. 19.

*** UNESCO, (2003). Towards integrated management of Alexandria's coastal heritage. Coastal region and small island papers 14, UNESCO, Paris, p. 80.

*** URBACO-EDR, (2007). Annaba, urban coherence scheme: Prospective diagnosis, Annaba, Algeria,p. 280.

*** WTO Committee for the Middle East, (2018), Annie's Report on Tourism Trends in the Middle East and North Africa, Sharm El Sheikh, p. 40.

Submitted:

17.01.2019
Revised:

02.04.2020
Accepted and published online 09.04 .2020 